\title{
ATTITUDES OF MENTALLY DISORDERED ADULTS TO COMMUNITY CARE
}

\author{
BY \\ ALISON C. CAMPBELL, M.A. (Sydney), Ph.D. (EDIN.) \\ Research Psychologist, Department of Social and Preventive Medicine, University of Manchester
}

The Mental Health Act, 1959, encouraged local authorities to provide community-based services for the mentally disordered. By the middle of 1966 Lancashire County Council had built thirteen mixed-sex hostels for mentally disordered adults. Residents come to the hostels from the community at large (e.g. when no longer able to live with family or friends), from other residential institutions, and from mental hospitals, mental subnormality hospitals, and the psychiatric wards of general hospitals. The hostels between them have 186 places for men and 169 for women. Residents are accommodated in hostels in their own home areas wherever possible.

The justification for community care rests ultimately on humane considerations. Of prime importance is the satisfaction and contentment of those being cared for. The author, however, knows of no published evidence about the type of care the mentally disordered themselves prefer, or what their attitudes and feelings are in this matter. While there are admitted difficulties in carrying out attitude surveys among the mentally disordered, these difficulties are not insuperable. The present com- munication gives an account of an inquiry into the attitudes to their present and past situations of 304 residents of the Lancashire County hostels.

\section{The SubJects}

In the summer of 1966 there were 316 mentally 은 disordered adults in the Lancashire County hostels, $\overrightarrow{ }$ and 304 of these residents were interviewed. Seven $\frac{7}{0}$ of the remaining twelve had no speech, one was too ill to be seen, and four were away from their hostel at $\vec{\varphi}$ the time of the visits. The 304 residents had been in 8 the hostels for between 9 days and 4 years 5 months with a mean length of stay of 1 year 4 months. The distribution by age, sex, and type of mental disorder is shown in Table I.

The mentally ill residents are significantly older than the subnormal and severely subnormal $(P<0 \cdot 001)$. No other differences are significant. (All statements of significance are based on $\chi^{2}$ tests and refer unless otherwise specified to the 0.05 significance level.) The distribution of residents by sex, type of mental disorder, and residence immediately before entering the hostels is shown in Table II (opposite).

TABLE I

DISTRIBUTION OF THE RESIDENTS OF THIRTEEN LOCAL AUTHORITY HOSTELS BY AGE, SEX AND TYPE OF MENTAL DISORDER

\begin{tabular}{|c|c|c|c|c|c|c|c|c|c|c|c|c|}
\hline \multirow{3}{*}{$\begin{array}{c}\text { Age Group } \\
\text { (yrs) }\end{array}$} & \multicolumn{4}{|c|}{ Males } & \multicolumn{4}{|c|}{ Females } & \multicolumn{4}{|c|}{ Both Sexes } \\
\hline & \multirow{2}{*}{ SN } & \multirow{2}{*}{ MI } & \multicolumn{2}{|c|}{ Total } & \multirow{2}{*}{$\mathbf{S N}$} & \multirow{2}{*}{ MI } & \multicolumn{2}{|c|}{ Total } & \multirow{2}{*}{ SN } & \multirow{2}{*}{ MI } & \multicolumn{2}{|c|}{ Total } \\
\hline & & & No. & Per cent. & & & No. & Per cent. & & & No. & Per cent. \\
\hline $\begin{array}{l}15-24 \\
25-34 \\
35-44 \\
45-54 \\
55-64 \\
65-74\end{array}$ & $\begin{array}{r}29 \\
25 \\
27 \\
37 \\
15 \\
1\end{array}$ & $\begin{array}{r}1 \\
2 \\
6 \\
12 \\
7 \\
1\end{array}$ & $\begin{array}{r}30 \\
27 \\
33 \\
49 \\
22 \\
2\end{array}$ & $\begin{array}{r}18 \\
17 \\
20 \\
30 \\
13 \\
1\end{array}$ & $\begin{array}{r}25 \\
22 \\
29 \\
26 \\
14 \\
2\end{array}$ & $\begin{array}{r}-3 \\
10 \\
9 \\
12 \\
1\end{array}$ & $\begin{array}{r}25 \\
25 \\
39 \\
35 \\
26 \\
3\end{array}$ & $\begin{array}{r}16 \\
16 \\
25 \\
23 \\
17 \\
2\end{array}$ & $\begin{array}{r}54 \\
47 \\
56 \\
63 \\
29 \\
3\end{array}$ & $\begin{array}{r}1 \\
5 \\
16 \\
21 \\
19 \\
2\end{array}$ & $\begin{array}{r}55 \\
52 \\
72 \\
84 \\
48 \\
5\end{array}$ & $\begin{array}{r}17 \\
16 \\
23 \\
27 \\
15 \\
2\end{array}$ \\
\hline Total & 134 & 29 & 163 & 100 & 118 & 35 & 153 & 100 & 252 & 64 & 316 & 100 \\
\hline Median Age & 39 & 49 & 42 & & 39 & 49 & 41 & & 39 & 49 & 41 & \\
\hline \multicolumn{13}{|c|}{$\begin{array}{c}\text { SN = subnormal or severely subnormal. } \\
94\end{array}$} \\
\hline
\end{tabular}


TABLE II

DISTRIBUTION OF THE RESIDENTS OF THIRTEEN LOCAL AUTHORITY HOSTELS BY SEX, TYPE OF MENTAL DISORDER, AND PLACE OF RESIDENCE IMMEDIATELY BEFORE ADMISSION TÓ HOSTEL

\begin{tabular}{|c|c|c|c|c|c|c|c|c|c|c|c|c|c|}
\hline & \multirow{3}{*}{ Previous Residence } & \multicolumn{4}{|c|}{ Males } & \multicolumn{4}{|c|}{ Females } & \multicolumn{4}{|c|}{ Both Sexes } \\
\hline & & \multirow{2}{*}{ SN } & \multirow{2}{*}{ MI } & \multicolumn{2}{|c|}{ Total } & \multirow{2}{*}{ SN } & \multirow{2}{*}{ MI } & \multicolumn{2}{|c|}{ Total } & \multirow{2}{*}{ SN } & \multirow{2}{*}{ MI } & \multicolumn{2}{|c|}{ Total } \\
\hline & & & & No. & Per cent. & & & No. & Per cent. & & & No. & Per cent. \\
\hline $\begin{array}{l}\text { In the } \\
\text { Com- } \\
\text { munity }\end{array}$ & $\begin{array}{l}\text { Home } \\
\text { Other residential accommodation } \\
\text { Other (e.g. lodgings) }\end{array}$ & $\begin{array}{r}34 \\
29 \\
1\end{array}$ & $\underline{2}$ & $\begin{array}{r}36 \\
29 \\
1\end{array}$ & $\begin{array}{l}23 \\
17 \\
-\end{array}$ & $\begin{array}{r}42 \\
26 \\
1\end{array}$ & $\underline{2}$ & $\begin{array}{r}44 \\
26 \\
1\end{array}$ & $\begin{array}{l}29 \\
17 \\
-\end{array}$ & $\begin{array}{r}76 \\
55 \\
2\end{array}$ & $\frac{4}{-}$ & $\begin{array}{r}80 \\
55 \\
2\end{array}$ & $\begin{array}{r}25 \\
17 \\
1\end{array}$ \\
\hline $\begin{array}{l}\text { In } \\
\text { Hospital }\end{array}$ & $\begin{array}{l}\text { Subnormality hospital } \\
\text { Mental hospital } \\
\text { General hospital } \\
\text { (psychiatric wards) }\end{array}$ & $\begin{array}{r}64 \\
2 \\
4\end{array}$ & $\begin{array}{r}3 \\
12 \\
12\end{array}$ & $\begin{array}{l}67 \\
14 \\
16\end{array}$ & $\begin{array}{r}41 \\
9 \\
10\end{array}$ & $\begin{array}{r}42 \\
4 \\
3\end{array}$ & $\begin{array}{r}\overline{26} \\
7\end{array}$ & $\begin{array}{l}42 \\
30 \\
10\end{array}$ & $\begin{array}{r}27 \\
20 \\
7\end{array}$ & $\begin{array}{r}106 \\
6 \\
7\end{array}$ & $\begin{array}{r}3 \\
38 \\
19\end{array}$ & $\begin{array}{r}109 \\
44 \\
26\end{array}$ & $\begin{array}{r}34 \\
15 \\
8\end{array}$ \\
\hline \multicolumn{2}{|l|}{ Total } & 134 & 29 & 163 & 100 & 118 & 35 & 153 & 100 & 252 & 64 & $\cdot 316$ & 100 \\
\hline
\end{tabular}

There is a significant sex difference in previous place of residence. Proportionately more males came from subnormality hospitals, while proportionately more females came from mental hospitals and, to a lesser extent, from their own homes. The proportion of residents from subnormality hospitals (34 per cent.) was the largest, with the second major source of residents being their own homes ( 25 per cent.). 43 per cent. of all residents had come from the community at large, and the remaining 57 per cent. from hospitals.

\section{METHOD}

All 304 residents were interviewed individually by the author. Many residents were very deficient in linguistic skills and the interviews were organized to take this into account. Major questions were phrased to require a choice of answers between two specified alternatives, e.g. Which place do you like best, here (the hostel) or $x$ (previous place of residence)? Questions requiring yes/no answers were avoided wherever possible, due to the tendency for mentally subnormal persons to answer "yes, yes" to all questions irrespective of content. Probing was done to assess the validity of each answer. Thus the question above might be followed up by asking, What is good about the hostel?, And what is bad? (What don't you like?), What was good about $x$ ?, What was bad?, Would you like to go back to $x$ ?, etc. These "probe" questions were varied to suit the individual. In seeking reasons for a given answer all statements freely offered by the subjects were accepted. If none was offered this had also to be accepted. When a resident said he preferred the hostel to hospital; that the hostel food was good and the rooms very nice; and that nothing was good about the hospital and he would not want to go back there, little doubt remained that this stated preference for the hostel reflected his true feelings. In other cases assessment is not so easy, particularly with residents at the lowest levels of linguistic skill. Tone of voice, facial expression, gesture, etc., were here extensively used as pointers to attitudes and opinions.

\section{Results AND Discussion}

Attitude to hostel as opposed to previous place of residence.

Data as to preferred place of residence are given in Table III. "Other" refers to other residential institutions (junior hostels, approved schools, old people's homes, etc.), and in two instances to private lodgings. That 73 per cent. of residents prefer the hostels to their previous place of residence is encouraging, since a statement of preference for one place rather than another can be taken to imply that the person is happier in that place. Hostels are in general preferred to hospital, other residential institutions or lodgings, but not to home. That 88 per cent. of former hospital patients prefer the hostels is of particular significance. It is evidence such as this, rather than economic or administrative considerations, that ulimately justifies the policy of community care. It may further be argued that, since mentally disordered adults who have lived both in hostels and hospitals on the whole prefer the

TABLE III

PREFERRED RESIDENCE BY PLACE OF RESIDENCE IMMEDIATELY BEFORE ENTERING HOSTEL

\begin{tabular}{|c|c|c|c|c|c|c|c|c|}
\hline \multirow{3}{*}{$\begin{array}{l}\text { Preferred } \\
\text { Residence }\end{array}$} & \multicolumn{6}{|c|}{ Previous Residence } & \multirow{2}{*}{\multicolumn{2}{|c|}{ Total }} \\
\hline & \multicolumn{2}{|c|}{ Home } & \multicolumn{2}{|c|}{ Hospital } & \multicolumn{2}{|c|}{ Other } & & \\
\hline & No. & $\begin{array}{c}\text { Per } \\
\text { cent. }\end{array}$ & No. & $\begin{array}{l}\text { Per } \\
\text { cent. }\end{array}$ & No. & $\begin{array}{l}\text { Per } \\
\text { cent. }\end{array}$ & No. & $\begin{array}{l}\text { Per } \\
\text { cent. }\end{array}$ \\
\hline $\begin{array}{l}\text { Hostel } \\
\text { Previous } \\
\text { residence } \\
\text { Undecided } \\
\text { *No usable } \\
\text { reply available }\end{array}$ & $\begin{array}{r}31 \\
37 \\
9 \\
3\end{array}$ & $\begin{array}{l}40 . \\
48 \\
12\end{array}$ & $\begin{array}{r}152 \\
12 \\
8 \\
7\end{array}$ & $\begin{array}{r}88 \\
7 \\
5\end{array}$ & $\begin{array}{r}31 \\
7 \\
7 \\
12\end{array}$ & $\begin{array}{l}70 \\
15 \\
15\end{array}$ & $\begin{array}{r}214 \\
56 \\
24 \\
22\end{array}$ & $\begin{array}{r}73 \\
19 \\
8\end{array}$ \\
\hline Total & 80 & 100 & 179 & 100 & 57 & 100 & 316 & 100 \\
\hline
\end{tabular}

*Percentages based on usable replies only. 
hostels, comparable mentally subnormal adults now living at home but who, in the future, come to need residential care will also be happier in hostels (assuming the pattern of hostel and hospital care has not by then changed). 41 per cent. of the 152 former hospital patients who expressed a preference for the hostels gave as their main reason the freedom of movement the hostels allow ("you are more free here"; "you can go out when you want"; "you are locked up in hospital"). 17 per cent. mentioned proximity to home and family; 15 per cent. the material comforts (food and accommodation) of the hostels; and 10 per cent. preferred the hostels because "the people (specifically staff) are nicer here and treat you better".

The twelve former hospital patients who preferred the hospital included nine men (7 subnormal and 2 mentally ill) and three women (1 subnormal and 2 mentally ill). They ranged in age from 17 to 66 (mean 42). Six of the twelve gave no particular reason for their preference; three preferred the hospital because their friends were there, two because they had "fallen out" with hostel residents (a transient phenomenon), and one because he found it "too noisy being with girls". This was the only suggestion of a complaint from the residents about both sexes being accommodated together.

\section{Attitude towards staying in a hostel all one's life}

Desire to stay in a hostel indefinitely is related to age, sex, and type of mental disorder in Tables IV and $V$. The question of staying in a hostel all one's life was not included in the interview schedule until three hostels had already been visited. Replies are therefore available for 244 residents only.

The 117 residents who did not want to stay in a hostel all their life included the twelve who wanted to go back to hospital, two who wanted to go back to Old People's Homes, and twenty who wanted a more independent life in lodgings. The remaining 83 all wanted to go home ("home is of course best of all"). A longing for home was expressed to a like degree by all residents, irrespective of whether they had a home
TABLE IV

DESIRE TO STAY IN HOSTEL INDEFINITELY, BY AGE

\begin{tabular}{|c|c|c|c|c|c|c|c|c|}
\hline \multirow{3}{*}{$\begin{array}{c}\text { Desire to Stay } \\
\text { in Hostel } \\
\text { Indefinitely }\end{array}$} & \multicolumn{6}{|c|}{ Age Group (yrs) } & \multirow{2}{*}{\multicolumn{2}{|c|}{ All Ages }} \\
\hline & \multicolumn{2}{|c|}{$16-35$} & \multicolumn{2}{|c|}{$36-55$} & \multicolumn{2}{|c|}{$56+$} & & \\
\hline & No. & $\begin{array}{l}\text { Per } \\
\text { cent. }\end{array}$ & No. & $\begin{array}{c}\text { Per } \\
\text { cent. }\end{array}$ & No. & $\begin{array}{c}\text { Per } \\
\text { cent. }\end{array}$ & No. & $\begin{array}{l}\text { Per } \\
\text { cent. }\end{array}$ \\
\hline $\begin{array}{l}\text { Yes } \\
\text { No } \\
\text { Undecided }\end{array}$ & $\begin{array}{r}24 \\
46 \\
5\end{array}$ & $\begin{array}{r}32 \\
61 \\
7\end{array}$ & $\begin{array}{l}60 \\
57 \\
14\end{array}$ & $\begin{array}{l}46 \\
44 \\
10\end{array}$ & $\begin{array}{r}21 \\
14 \\
4\end{array}$ & $\begin{array}{l}54 \\
36 \\
10\end{array}$ & $\begin{array}{r}105 \\
117 \\
22\end{array}$ & $\begin{array}{r}43 \\
48 \\
9\end{array}$ \\
\hline Total & 75 & 100 & 130 & 100 & 39 & 100 & 244 & 100 \\
\hline
\end{tabular}

and irrespective of their previous place of residence. $\vec{\circ}$ Even people who had been in hospital for 30 years or $\overrightarrow{\vec{H}}$ more and had had no contact with their families in the meantime expressed a desire to go back home. $\overrightarrow{\mathrm{D}}$ A naive belief in the strength of family ties seems to? survive all abandonment, rejection, and ill-treat- $N$ ment. The younger residents, significantly more of $\tilde{N}$ whom have homes to go to, were the least inclined to want to stay in a hostel all their life. Significantlyo more men did not want to stay in a hostel all their life than women. The sex difference in the proportion $>$ of residents having a home was not however significant (70 per cent. for men and 74 per cent. for $\vec{\varphi}$ women). The mentally ill differ significantly in attitude from the subnormal and severely subnorma proportionately more mentally ill residents beipg "undecided" whether they want to stay in a hostel 迎1 their life or not. This may be due to the mentally illo having more insight into their situation, as exempli-⿳亠丷厂

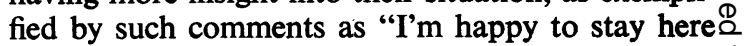
now but I might want to move out later, if I get on $\vec{\circ}$ my feet again".

Attitude to attending an Adult Training Centre as opposed to outside employment

Each hostel has an Adult Training Centre alongside, which the majority of residents attend. Data on:attitude towards attending the Centres as opposed to $\underline{3}$. being in outside employment are shown in Table VIo̊ (opposite).

Data on desire for a job are available for 3060 residents. This is because two residents who were

TABLE V

DESIRE TO STAY IN HOSTEL INDEFINITELY, BY SEX AND TYPE OF MENTAL DISORDER

\begin{tabular}{|c|c|c|c|c|c|c|c|c|c|c|c|c|}
\hline \multirow{3}{*}{$\begin{array}{l}\text { Desire to Stay in } \\
\text { Hostel Indefinitely }\end{array}$} & \multicolumn{4}{|c|}{ Males } & \multicolumn{4}{|c|}{ Females } & \multicolumn{4}{|c|}{ Both Sexes } \\
\hline & \multirow{2}{*}{$\mathbf{S N}$} & \multirow{2}{*}{ MI } & \multicolumn{2}{|c|}{ Total } & \multirow{2}{*}{ SN } & \multirow{2}{*}{ MI } & \multicolumn{2}{|c|}{ Total } & \multirow{2}{*}{$\mathbf{S N}$} & \multirow{2}{*}{ MI } & \multicolumn{2}{|c|}{ Total } \\
\hline & & & No. & Per cent. & & & No. & Per cent. & & & No. & Per cent. \\
\hline $\begin{array}{l}\text { Yes } \\
\text { No } \\
\text { Undecided }\end{array}$ & $\begin{array}{r}41 \\
65 \\
9\end{array}$ & $\begin{array}{r}6 \\
10 \\
5\end{array}$ & $\begin{array}{l}47 \\
75 \\
14\end{array}$ & $\begin{array}{l}35 \\
55 \\
10\end{array}$ & $\begin{array}{r}45 \\
34 \\
3\end{array}$ & $\begin{array}{r}13 \\
8 \\
5\end{array}$ & $\begin{array}{r}58 \\
42 \\
8\end{array}$ & $\begin{array}{r}54 \\
39 \\
7\end{array}$ & $\begin{array}{l}86 \\
99 \\
12\end{array}$ & $\begin{array}{l}19 \\
18 \\
10\end{array}$ & $\begin{array}{r}105 \\
117 \\
22\end{array}$ & $\begin{array}{r}43 \\
48 \\
9\end{array}$ \\
\hline Total & 115 & 21 & 136 & 100 & 82 & 26 & 108 & 100 & 197 & 47 & 244 & 100 \\
\hline
\end{tabular}


TABLE VI

DESIRE FOR A JOB, BY PRESENT OCCUPATION

\begin{tabular}{c|c|c|c|c|c}
\hline \multirow{2}{*}{$\begin{array}{c}\text { Desire for a } \\
\text { Job }\end{array}$} & \multicolumn{2}{|c|}{ Present Occupation } & \multicolumn{2}{c}{ Total } \\
\cline { 2 - 6 } & $\begin{array}{c}\text { Training } \\
\text { Centre }\end{array}$ & Job* & Othert & No. & Per cent. \\
\hline Yes & 152 & 30 & - & 182 & 60 \\
No \\
Undecided & 101 & - & 1 & 102 & 33 \\
& 22 & - & - & 22 & 7 \\
\hline Total & 275 & 30 & 1 & 306 & 100 \\
\hline
\end{tabular}

*Includes five people employed part time and attending Training Centre the rest of the time.

tOne female resident aged $67 \mathrm{had}$ lost an arm and was not fit to attend a Training Centre. She spent her day helping in the hostel.

away from the hostels at the time of the visits were already in outside employment, had always wanted a job, and were known to prefer outside employment to attending the Centre. There was no association between being in outside employment and having had a job in the past. Of the thirty people already in a job fifteen had never worked before in their life. Nor was there any association between wanting a job and having had a job in the past. Desire for a job according to previous place of residence and type of mental disorder is shown in Table VII.

There is a tendency $(0.10>\mathrm{P}>0.05)$ for people from hospital to be more eager for a job than people from home or other accommodation. Many of these latter have been at a Training Centre for years, and may have become so "institutionalized" to the Centre as not to want to leave. There is also the possibility that people from hospital, after years of separation from society, are particularly eager to "prove" themselves. Obtaining outside employment is an effective way of doing so. There was a tendency for proportionately more of the subnormal and severely subnormal to express a desire for a job than the mentally ill $(0 \cdot 10>\mathrm{P}>0 \cdot 05)$. A number of those expressing a desire for a job were certainly being unrealistic, and it may be that the mentally ill have more insight into their condition, and are more realistic in their assessment, and hence more favourably disposed towards (or reconciled to) the Training Centres.

116 of the 182 people who preferred outside employment gave one or more reasons for their choice:

\begin{tabular}{|c|c|c|}
\hline \multicolumn{2}{|r|}{ Reasons } & $\begin{array}{l}\text { Number of } \\
\text { Times Given }\end{array}$ \\
\hline Positive & $\begin{array}{l}\text { More money in a job } \\
\text { Greater independence } \\
\text { Can meet new people } \\
\text { Always been used to a job }\end{array}$ & $\left.\begin{array}{r}59 \\
5 \\
4 \\
4\end{array}\right\} 72$ \\
\hline Negative & $\begin{array}{l}\text { Work at Training Centre } \\
\text { dull and boring; not } \\
\text { "proper work" } \\
\text { General dislike of Train- } \\
\text { ing Centre (unspecified) }\end{array}$ & $\left.\begin{array}{l}39 \\
5\end{array}\right\} 44$ \\
\hline
\end{tabular}

The mentally disordered, like the rest of the population, are strongly motivated by financial reward. The mentally disordered are also capable, like the rest of the population, of finding work dull and boring. Eighteen of the 39 who complained that work at the Training Centre was "dull and boring" had been in jobs and knew what outside work was like; 35 of these 39 people were mentally subnormal. It is frequently assumed that the mentally subnormal enjoy simple repetitive tasks and lack the capacity for being bored. This is clearly not always so. It has been pointed out by Cashdan and Stevens (1966) that the notion that subnormal persons are rigid and perseverative was derived in the main from observation in large-scale institutions, and that the rigidity and perseveration were largely produced by the institutional regime.

With respect to the 102 people who preferred the Training Centres to outside employment, 46 supported their choice with one or more reasons. Thirty liked the work at the Training Centres, or the people, or both. The other sixteen felt that they could not cope with a job because of age or infirmity.

TABLE VII

DESIRE FOR A JOB, BY PREVIOUS PLACE OF RESIDENCE AND TYPE OF MENTAL DISORDER

\begin{tabular}{|c|c|c|c|c|c|c|c|c|c|c|c|c|c|c|c|c|}
\hline \multirow{4}{*}{$\begin{array}{l}\text { Desire for } \\
\text { a Job }\end{array}$} & \multicolumn{12}{|c|}{ Previous Place of Residence } & \multirow{2}{*}{\multicolumn{4}{|c|}{ All Residents }} \\
\hline & \multicolumn{4}{|c|}{ Home } & \multicolumn{4}{|c|}{ Hospital } & \multicolumn{4}{|c|}{ Other Accommodation } & & & & \\
\hline & \multirow{2}{*}{ SN } & \multirow{2}{*}{ MI } & \multicolumn{2}{|c|}{ Total } & \multirow{2}{*}{ SN } & \multirow{2}{*}{ MI } & \multicolumn{2}{|c|}{ Total } & \multirow{2}{*}{ SN } & \multirow{2}{*}{ MI } & \multicolumn{2}{|c|}{ Total } & \multirow{2}{*}{ SN } & \multirow{2}{*}{ MI } & \multicolumn{2}{|c|}{ Total } \\
\hline & & & No. & Per cent. & & & No. & Per cent. & & & No. & Per cent. & & & No. & Per cent. \\
\hline $\begin{array}{l}\text { Yes } \\
\text { No } \\
\text { Undecided }\end{array}$ & $\begin{array}{r}37 \\
31 \\
7\end{array}$ & $\begin{array}{l}1 \\
1 \\
2\end{array}$ & $\begin{array}{r}38 \\
32 \\
9\end{array}$ & $\begin{array}{l}48 \\
41 \\
11\end{array}$ & $\begin{array}{c}75 \\
32 . \\
7\end{array}$ & $\begin{array}{r}29 \\
24 \\
5\end{array}$ & $\begin{array}{r}104 \\
56 \\
12\end{array}$ & $\begin{array}{r}60 \\
33 \\
7\end{array}$ & $\begin{array}{r}40 \\
12 \\
3\end{array}$ & $\begin{array}{l}0 \\
0 \\
0\end{array}$ & $\begin{array}{r}40 \\
12 \\
3\end{array}$ & $\begin{array}{r}73 \\
22 \\
5\end{array}$ & $\begin{array}{r}152 \\
75 \\
17\end{array}$ & $\begin{array}{r}30 \\
27 \\
5\end{array}$ & $\begin{array}{r}182 \\
102 \\
22\end{array}$ & $\begin{array}{r}60 \\
33 \\
7\end{array}$ \\
\hline Total & 75 & 4 & 79 & 100 & 114 & 58 & 172 & 100 & 55 & $\mathbf{0}$ & 55 & 100 & 244 & 62 & 306 & 100 \\
\hline
\end{tabular}


Data on desire for a job according to desire to stay in a hostel indefinitely, for the 244 residents for whom replies are available on the latter question, are given in Table VIII.

TABLE VIII

DESIRE FOR A JOB, BY DESIRE TO STAY IN HOSTEL INDEFINITELY

\begin{tabular}{l|r|r|r|r|r|r|r|r}
\hline \multirow{2}{*}{$\begin{array}{l}\text { Desire for } \\
\text { a Job }\end{array}$} & \multicolumn{6}{|c|}{ Desire to Stay in Hostel Indefinitely } \\
\cline { 2 - 9 } & \multicolumn{2}{|c|}{ Yes } & \multicolumn{2}{|c|}{ No } & \multicolumn{2}{|c|}{ Undecided } & \multicolumn{2}{c}{ Total } \\
\cline { 2 - 9 } & & $\begin{array}{r}\text { Per } \\
\text { cent. }\end{array}$ & No. & $\begin{array}{r}\text { Per } \\
\text { cent. }\end{array}$ & No. & $\begin{array}{c}\text { Per } \\
\text { cent. }\end{array}$ & No. & $\begin{array}{c}\text { Per } \\
\text { cent. }\end{array}$ \\
\hline Yes & 47 & 44 & 84 & 72 & 14 & 67 & 145 & 60 \\
No \\
Undecided & 49 & 46 & 29 & 25 & 3 & 14 & 81 & 33 \\
\hline Total & 10 & 10 & 4 & 3 & 4 & 19 & 18 & 7 \\
\hline
\end{tabular}

A significantly higher proportion of those who did not want to stay in a hostel indefinitely, or were undecided, desired outside employment $(P<0.001)$. A number of those expressing a desire for outside employment did seem fit for a job, if suitable work and a "sympathetic employer" could be found. More attention could be given to the seeking of jobs for hostel residents and more might be done to encourage hostel wardens, Training Centre supervisors, and other interested parties to give informal assistance to the Mental Welfare Officer in this aspect of his duties.

Attitude towards sharing or not sharing a bedroom Data on preferences with respect to bedroom accommodation are set out in Table IX.

Significantly more of those from home and other accommodation prefer a single room than those from hospital. Former hospital patients, used to living on a ward, find the transition to a single room too abrupt. While 58 per cent. of the 297 residents for whom replies are available preferred a single room, the hostels have single rooms for 20 per cent. of residents only. In its most recent hostels Lancashire County Council is now providing single rooms for
52 per cent. of residents (sixteen single rooms in a $\mathscr{O}$ 31-place hostel). If residents are to be accommodated according to their wishes, it may be necessary in the $\frac{3}{8}$ future to increase the proportion of single rooms still ?. further. After a certain time in three- or four-bedded $\overrightarrow{\vec{D}}$ rooms those from hospital may decide that they would like a single room. Once the backlog of hospital patients awaiting transfer to hostels has been dealt with, the hostels are likely to draw their residents increasingly from people living at home. Proportionately more people from their own homes $\delta$ prefer single rooms. 143 of the 174 people expressing $\vec{\circ}$ a preference for a single room gave one or more reasons for their choice, as follows:

$\left.\begin{array}{l|r}\hline \multicolumn{1}{c|}{\text { Reason }} & \begin{array}{c}\text { Number of } \\ \text { times mentioned }\end{array} \\ \hline \text { More private } & 72 \\ \text { Quieter } & 52 \\ \text { Can arrange room to suit yourself } & 16 \\ \text { Always had a single } & 12 \\ \text { Sharing leads to fallings-out; etc. } & 4 \\ \text { Other people dirty; have germs; etc. } & 4\end{array}\right\}$

* Seventeen people gave two main reasons, hence the total of 160 .

72 of the 91 people who preferred sharing a roof gave reasons for their choice, as follows:

\begin{tabular}{|c|c|}
\hline Reason & $\begin{array}{l}\text { Number of } \\
\text { times mentioned }\end{array}$ \\
\hline $\begin{array}{l}\text { Likes company } \\
\text { Nervous on own } \\
\text { Epileptic and might need help in the } \\
\text { night } \\
\text { Likes being responsible for others } \\
\text { (e.g. epileptics) } \\
\text { Used to sharing }\end{array}$ & $\left.\begin{array}{r}54 * \\
9 \\
5 \\
2 \\
2\end{array}\right\} 72$ \\
\hline
\end{tabular}

*33 of these were former hospital patients who had long been used to shared accommodation.

TABLE IX

PREFERRED BEDROOM ACCOMMODATION BY ACTUAL BEDROOM ACCOMMODATION AND PREVIOUS PLACE OF RESIDENCE

\begin{tabular}{|c|c|c|c|c|c|c|c|c|c|c|c|c|c|c|c|c|}
\hline \multirow{4}{*}{$\begin{array}{l}\text { Preferred Bedroom } \\
\text { Accommodation }\end{array}$} & \multicolumn{12}{|c|}{ Previous Place of Residence } & \multirow{2}{*}{\multicolumn{4}{|c|}{ All Residents }} \\
\hline & \multicolumn{4}{|c|}{ Home } & \multicolumn{4}{|c|}{ Hospital } & \multicolumn{4}{|c|}{ Other Accommodation } & & & & \\
\hline & \multirow{2}{*}{ Single } & \multirow{2}{*}{ Shared } & \multicolumn{2}{|c|}{ Total } & \multirow{2}{*}{ Single } & \multirow{2}{*}{ Shared } & \multicolumn{2}{|c|}{ Total } & \multirow{2}{*}{ Single } & \multirow{2}{*}{ Shared } & \multicolumn{2}{|c|}{ Total } & \multirow{2}{*}{ Single } & \multirow{2}{*}{ Shared } & \multicolumn{2}{|c|}{ Total } \\
\hline & & & No. & $\begin{array}{l}\text { Per } \\
\text { cent. }\end{array}$ & & & No. & $\begin{array}{l}\text { Per } \\
\text { cent. }\end{array}$ & & & No. & $\begin{array}{l}\text { Per } \\
\text { cent. }\end{array}$ & & & No. & $\begin{array}{l}\text { Per } \\
\text { cent. }\end{array}$ \\
\hline $\begin{array}{l}\text { Single } \\
\text { Shared } \\
\text { Undecided }\end{array}$ & $\frac{22}{-}$ & $\begin{array}{r}31 \\
19 \\
6\end{array}$ & $\begin{array}{r}53 \\
19 \\
6\end{array}$ & $\begin{array}{r}68 \\
24 \\
8\end{array}$ & $\begin{array}{r}22 \\
2 \\
2\end{array}$ & $\begin{array}{l}61 \\
58 \\
21\end{array}$ & $\begin{array}{l}83 \\
60 \\
23\end{array}$ & $\begin{array}{l}50 \\
36 \\
14\end{array}$ & $\frac{16}{1}$ & $\begin{array}{r}22 \\
12 \\
2\end{array}$ & $\begin{array}{r}38 \\
12 \\
3\end{array}$ & $\begin{array}{r}72 \\
23 \\
5\end{array}$ & $\begin{array}{r}60 \\
2 \\
3\end{array}$ & $\begin{array}{r}114 \\
89 \\
29\end{array}$ & $\begin{array}{r}174 \\
91 \\
32\end{array}$ & $\begin{array}{l}58 \\
31 \\
11\end{array}$ \\
\hline Total & 22 & 56 & 78 & 100 & 26 & 140 & 166 & 100 & 17 & 36 & 53 & 100 & 65 & 232 & 297 & 100 \\
\hline
\end{tabular}


Summary AND Conclusions

An attitude survey was undertaken among the 316 residents of thirteen Lancashire County Council hostels for mentally disordered adults. Attention was focused on attitudes towards the hostels as opposed to previous place of residence; staying in a hostel all one's life; attending an Adult Training Centre as opposed to outside employment; and sharing or not sharing a bedroom. Attitudes towards the hostels were generally favourable, especially when hostels were compared with hospitals. 48 per cent. of 244 residents for whom replies were available on the issue did not, however, want to stay in a hostel all their life. Most of these people wanted to go home, irrespective of home conditions. 55 per cent. of 275 residents attending Adult Training Centres said they would prefer outside employment. 49 per cent. of 232 people sharing a bedroom would rather have had a single room. It is concluded that hostel care is preferred by the mentally disordered themselves, but there is still room for further improvement in the services provided.

The research reported herein is sponsored by the Ministry of Health and was initiated by $\mathrm{Dr} \mathrm{M}$. W. Susser, formerly of the University of Manchester, in conjunction with Dr Joyce E. Leeson. My thanks are due to Dr S. G. Gawne, Lancashire County Medical Officer of Health, and to the staff and residents of the Lancashire County hostels for their willing co-operation in the study.

\section{REFERENCE}

Cashdan, A., and Stevens, M. (1966). "Social Education in the Junior Training Centre", in "Application of Research to the Education and Training of the Severely Subnormal Child", J. ment. Subn., Monograph Supplement, pp. 1-10. 